\title{
MALDI-TOF MS IDENTIFICATION OF CITROBACTER YOUNGAE ISOLATED FROM FOOD
}

\author{
Dubravka S. Milanov* $^{* 1}$, Milan D. Đilas ${ }^{2}$, Jelena M. Babić ${ }^{1}$, Bojana Z. Prunić ${ }^{1}$, Maja J. Velhner ${ }^{1}$ \\ ${ }^{1}$ Scientific Veterinary Institute 'Novi Sad', Rumenački put 20, 21000 Novi Sad, Serbia \\ 2 Institute of Public Health of Vojvodina, Futoška 121, Novi Sad, Serbia
}

\author{
${ }^{\star}$ Corresponding author \\ Tel.: +381214895346 \\ E-mail: dubravka@niv.ns.ac.rs
}

\begin{abstract}
Salmonella-like bacteria, such as certain species of the Citrobacter genus are sometimes isolated from food and feed. By testing their biochemical and, partially, serological characteristics (according to the regulations given in the ISO 6579-1:2017 Standard) it is impossible to completely reject their affiliation to the Salmonella genus. In addition to this, the food microbiology laboratories usually lack diagnostic tools and procedures for precise identification of these isolates to the species level. Thus, it is considered useful to describe the identification of Citrobacter youngae species using MALDI-TOF MS (Matrix-Assisted Laser Desorption/Ionization Time-of-Flight Mass Spectrometry). Besides differential diagnostic criteria for distinguishing between Salmonella spp. and Citrobacter youngae, in this communication the relevant data on Citrobacter spp., the emerging opportunistic pathogenic member of Enterobacteriaceae family were presented.
\end{abstract}

Key words: Salmonella-like bacteria, cheese

\section{A REPORT ON A LABORATORY CASE}

A sample of soft, medium-fat cheese sprinkled with spices, produced in a small scale plant, was examined for the presence of Salmonella spp. in the Laboratory of Food Microbiology of the Scientific Veterinary Institute in Novi Sad. The sample was tested in accordance with the requirements of the ISO 6579-1:2017 Standard. Characteristic pink colonies with a black centre of Salmonella species on XLD agar (Biokar Diagnostics, France) were isolated from the sample and futher examined.

With tests of catalase (positive) and oxidase (negative) it was confirmed that the isolate belonged to the Enterobacteriaceae family. The biochemical characteristics of the isolate were assessed in accordance with the ISO 6579-1:2017 Standard (Table 1), plus using the methylred and citrate utilization tests, which were both positive (Figure 2).

Rapid slide agglutination test with the polyvalent serum for Salmonella groups A, B, $C, D$ and $E$ (Institute for Public Health of Serbia, Belgrade, Serbia) was positive but not with the group-specific sera $B(0: 4)$, D1 (O:9), C1 (O:7), C2-C3 (O:8), B (O:4) and $\mathrm{E} 1(\mathrm{O}: 3,10)$.

Based on the negative reaction of lysine decarboxylase and the production of $\beta$-galactosidase, with $95 \%$ and $99 \%$ probability, respectively, the hypothesis that the isolate belonged to Salmonella genus was ruled out. 


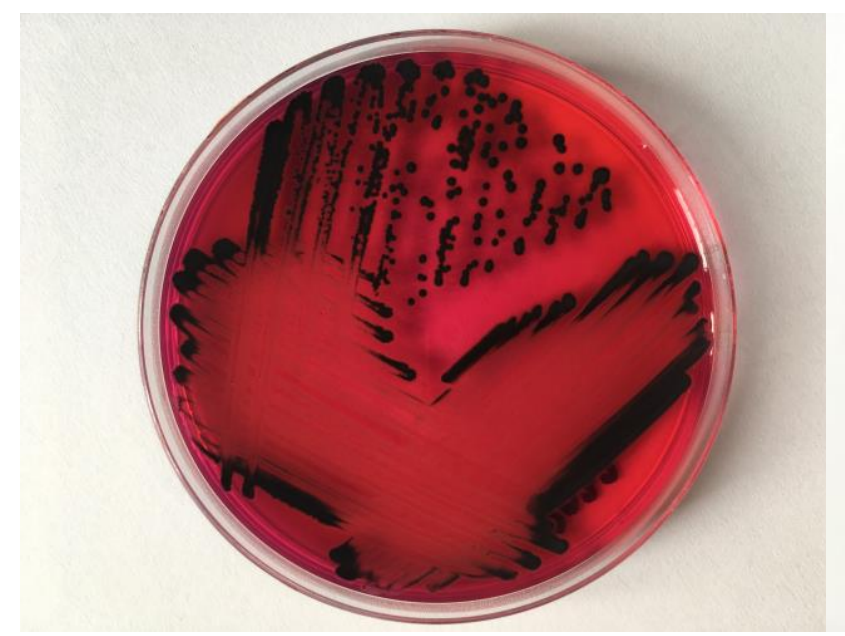

A. Bacterial colonies isolated from the cheese sample

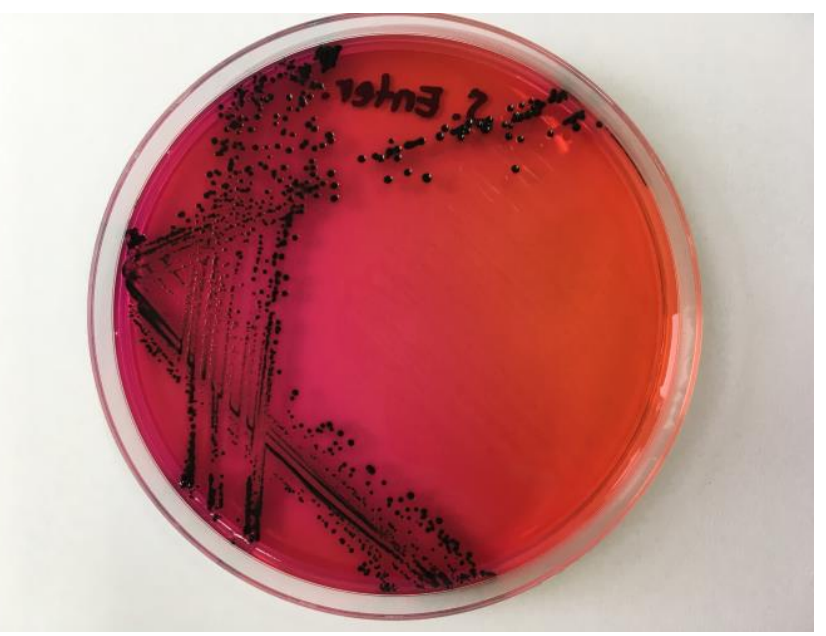

B. Colonies of the reference Salmonella Enteritidis ATCC 13076 culture

Figure 1. Colonies on XLD agar medium after $24 \mathrm{~h}$ incubation at $37^{\circ} \mathrm{C}$

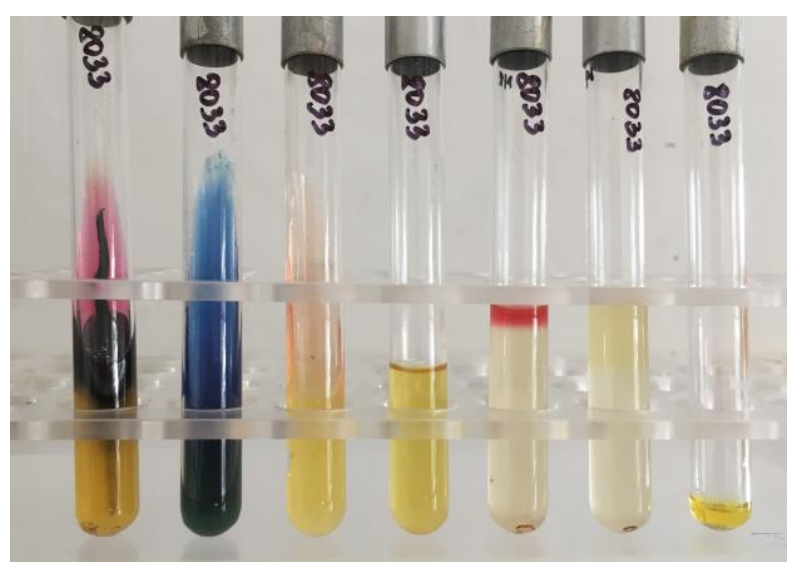

C. Isolate from the cheese sample

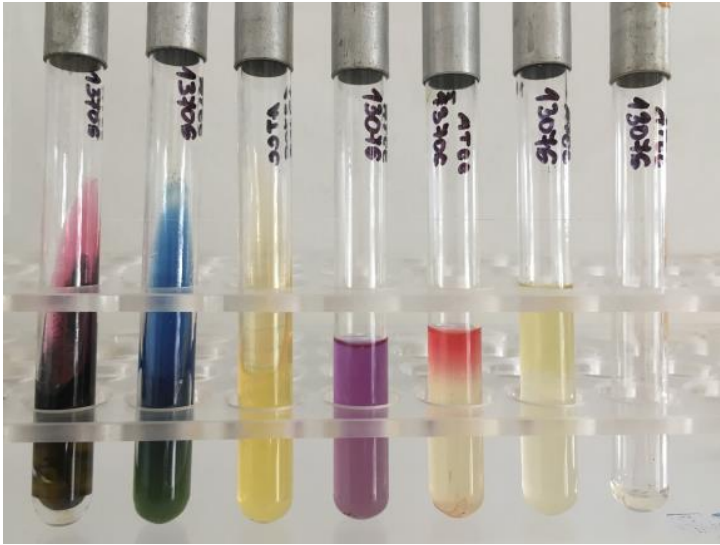

D. Positive control: Salmonella Enteritidis ATCC 13076

From left to right: Kligler, citrate, urea, lysine decarboxylase, methyl red, indole, $\beta$-galactosidase (ONPG disk)

Figure 2. Results of biochemical testing

Table 1.

Results of biochemical tests

\begin{tabular}{|c|c|c|c|}
\hline \multirow{2}{*}{ Test } & \multirow[t]{2}{*}{ Isolate } & \multicolumn{2}{|c|}{ Other strains* } \\
\hline & & Reaction & $\%$ ** \\
\hline $\mathrm{TSI}^{* * *}$ acid from glucose & + & + & 100 \\
\hline TSI gas from glucose & - & + & 92 \\
\hline TSI acid from lactose & - & - & 1 \\
\hline TSI hydrogen sulfide produced & + & + & 92 \\
\hline Urea hydrolysis & - & - & 1 \\
\hline Lysine decarboxylation & - & + & 95 \\
\hline Production of indole & - & - & 2 \\
\hline$\beta$-galactosidase & + & - & 1 \\
\hline \multicolumn{4}{|c|}{$\begin{array}{l}\text { *Interpretation of biochemical tests for other Salmonella strains (does not refer to the following species: S. typhi, } \\
\text { S. paratyphi A, B and C; S. Gallinarum biovar gallinarum and biovar pullorum); } \\
{ }^{* *} \text { Percentages indicate that not all isolates of Salmonella serovars show the reactions marked + or -. Reaction } \\
\text { may also vary between and within serovars; } \\
* * * \text { TSI-Triple sugar iron } \\
\text { (Source: ISO } 6579-1: 2017, p .10)\end{array}$} \\
\hline
\end{tabular}




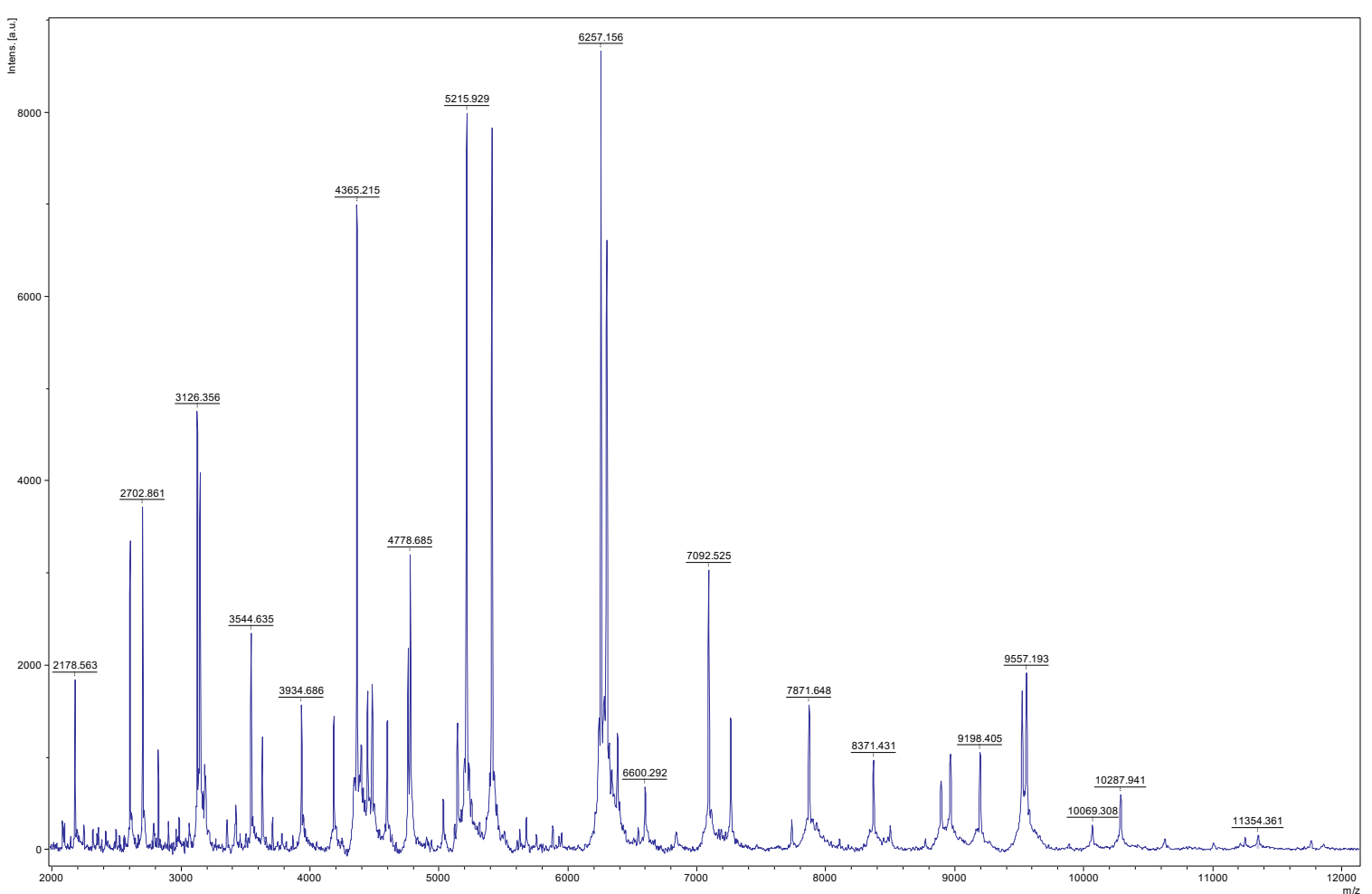

Figure 3. Spectra of Citrobacter youngae isolate generated by the MALDI-TOF Bruker Biotyper. The xaxis shows the masses $(\mathrm{m} / \mathrm{z})$ of the ions, and the $y$-axis shows the absolute intensities of the ions.

The $\mathrm{m} / \mathrm{z}$ values represent the mass-to-charge ratio

Based on the positive test for glucose fermentation, citrate utilization test, methyl red and $\beta$-galactosidase activity, as well as the characteristic appea-rance of the colonies on the XLD agar medium, the diagnostic assumption was that the isolate belonged to Citrobacter genus. Moreover, the bacterial culture produced a putrefaction smell, which is not characteristic of Salmonella species. In order to identify the species, the isolate was further processed at the Institute for Public Health of Vojvodina in Novi Sad, Serbia.

\section{MALDI-TOF MS analysis}

The isolate was prepared using the standard Bruker's direct transfer sample preparation procedure for MALDI-TOF MS. A single bacterial colony was spotted directly onto a MALDI target plate (Bruker Daltonics, Germany), allowed to dry and immediately overlaid with $1.0 \mu \mathrm{L}$ of the matrix solution (Bruker Matrix HCCA; $\alpha$-Cyano-4hydroxycinnamic acid).

MALDI-TOF mass spectra were obtained using Microflex LT/SH Biotyper spectrometer (Bruker Daltonics, Germany) equipped with a nitrogen laser $(337 \mathrm{~nm})$ under the control of flexControl software ver. 3.4 (Bruker Daltonics). Spectra in the mass range of 2 to $20 \mathrm{kDa}$ were collected by accumulating 240 laser shots (laser frequency, $60 \mathrm{~Hz}$; ion source 1 voltage, 20 $\mathrm{kV}$; ion source 2 voltage, $18.15 \mathrm{kV}$; lens voltage, $6 \mathrm{kV}$ ) at $30-40 \%$ of maximum laser power.

\section{COMMENT}

The most important food borne pathogens belong to the Enterobacteriaceae family. These are Salmonella spp., Yersinia enterocolitica, pathogenic Escherichia coli and Shigella spp. Some members of the family, for instance, Providencia alcalifaciens, Klebsiella spp., Serratia spp. and Citrobacter spp., are emerging opportunistic pathogens (Baylis et al., 2011). Based on the results of DNA hybridization assay, Citrobacter are classified into 11 species: C. amalonaticus, C. braakii, $C$. farmeri, C. freundii, C. gillenii, C. koseri, $C$. murliniae, $C$. rodentium, $C$. sedlakii, $C$. werkmanii and $C$. youngae (Brener et al., 1993). Citrobacter spp. are typically motile bacteria, owing the peritrichous flagellae, facultative anaerobic, usually oxidase ne- 
gative, and positive for catalase and methyl red (Doran, 1998; Duman et al., 2017). They generally utilize citrate as the only carbon source, which explains the etymology of the name of the genus (Arens et al., 1996). Two additional properties of citrobacteria which help to distinguish them from other members of the family Enterobacteriaceae are their failure to produce acetylmethylcarbinol (negative Voges-Proskauer test) and the lack of lysine decarboxylase (Janda et al., 1994).

Citrobacter species are present in water, soil, food and the intestinal tracts of animals and humans (Doran, 1998; Baylis et al., 2011; Clermont et al., 2015), and are commonly recovered from human faecal/intestinal flora (Duman et al., 2017). They can cause urinary infections, hospital-acquired bacteremiae, brain abscessses, neonatal meningitis, wound infections, pneumoniae, abscess, septicaemiae, endocarditis and diarrhoea (Arens et al., 1996; Doran, 1998; Clermont et al. 2015). Citrobacter spp. are also considered to be capable of causing gastrointestinal infections especially in infants and young children (Janda et al., 1994).

An outbreak of haemolytic uraemic syndrome (HUS) in Germany was linked to the consumption of butter containing parsley contaminated with $C$. freundii carrying the vtx2 gene (Tschape et al., 2011). The infections most often occur in neonates and immunocompromised people (Thurm and Gericke, 1994; Doran, 1998). C. freundii and $C$. koseri are the two most common clinical isolates. The other nine Citrobacter species, including C. youngae, rarely cause infections (Samonis et al., 2009).

The species identification of isolates belonging to the genus Citrobacter can be tentatively made using biochemical profiles or matrix-assisted laser desorption/ionization time-of-flight mass spectroscopy (MALDI-TOF MS) (Clermont et al., 2015; Kwak et al., 2015). MALDI-TOF MS has been described in the iden-tification of Citrobacter isolates from cli-nical samples (Kolinska et al., 2015). Online search retrieved a single report on the use of
MALDI-TOF MS in the iden-tification of Citrobacter species in food samples originnating from pork (Kwak et al., 2015).

Within less than a decade MALDI-TOF MS has become a gold standard in clinical microbiology laboratories, as it represents a powerful, rapid, precise, and cost-effective method for identification of bacteria, mycobacteria, and fungi, compared to conventional phenotypic techniques or molecular biology.

MALDI-TOF MS is able to detect a large spectrum of proteins, allowing the discrimination between closely related species and identification at the species and subspecies levels (Biswas and Rolan, 2012; Murray, 2012).

This technique allows desorption of peptides and proteins from both whole different cultured bacteria and crude bacterial extracts (Biswas and Rolan, 2012).

Usually, a single bacterial colony is enough for MALDI-TOF MS analysis (Dekker and Branda, 2011). Bacterial colonies are removed from agar culture plates, mixed with a matrix compound, and dried on steel target plates. The dried preparations are exposed to laser pulses, resulting in energy transfer from the matrix to the nonvolatile analyte molecules, with desorption of analyte into the gas phase.

The ionized molecules are accelerated by electric potentials through a flight tube to the mass spectrometer, with separation of the biomarkers determined by their mass/charge ratio $(\mathrm{m} / \mathrm{z})$. The profile of biomarkers is then compared with profiles of a collection of well characterized organisms included in the database (Murray, 2012).

This short communication can serve as a practical guide to the laboratories for food and feed control as to why and when to suspect the presence of this bacterial species. In order to achieve food safety monitoring and obtain precise data on the opportunistic pathogen species which can be transferred to consumers by food a continuous cooperation between laboratories for microbiological control of food and those dealing with public health is inevitable. 


\section{ACKNOWLEDGEMENTS}

This work was supported by the grant provided by the Ministry of Education, Science and Technological Development of the Republic of Serbia for the Project No. TR31071.

\section{REFERENCES}

1. Arens, S., Verhaegen, J., Verbist, L. (1996). Differentiation and susceptibility of Citrobacter isolates from patients in a university hospital. Clinical Microbiology and Infection, 3 (1), 53-57.

2. Biswas, S., Rolan, J.M. (2013). Use of MALDITOF mass spectrometry for identification of bacteria that are difficult to culture. Journal of Microbiological Methods, 92, 14-24.

3. Brenner, D.J., Grimont, P.A., Steigerwalt, A.G., Fanning, G.R., Ageron, E., Riddle, C.F. (1993). Classification of citrobacteria by DNA hybridization: designation of Citrobacter farmeri sp. nov., Citrobacter youngae sp. nov., Citrobacter braakii sp. nov., Citrobacter werkmanii sp. nov., Citrobacter sedlakii sp. nov., and three unnamed Citrobacter genomospecies. International Journal of Systematic Bacteriology, 43 (4), 645-658.

4. Baylis, C., Uyttendaele, M., Joosten, H., Davies, A. (2011). The Enterobacteriaceae and their significance to the food industry. ILSI Europe Report Studies, ILSI International Life Sciences Institute, ILSI Europe a.i.s.b.I., Belgium.

(http://ilsi.eu/wp-

content/uploads/sites/3/2016/06/EP-

Enterobacteriaceae.pdf).

5. Clermont, D., Motreff, L., Passet, V., Fernandez, J.C., Bizet, C., Brisse, S. (2015). Multilocus sequence analysis of the genus Citrobacter and description of Citrobacter pasteurii sp. nov. International Journal of Systematic and Evolutionary Microbiology, 65, 1486-1490.

6. Dekker, J.P., Branda, J.A. (2011). MALDI-TOF Mass Spectrometry in the clinical microbiology laboratory. Clinical Microbiology Newsletter, 33 (12), 87-93.

7. Doran, T.I. (1998). The role of Citrobacter in clinical disease of children: review. Clinical Infectious Diseases, 28, 384-94.

8. Duman M, Saticioglua, I.B., Buyukekiza, A.G., Baltab, F., Altuna S. (2017). Molecular charac- terization and antimicrobial resistance profile of atypical Citrobacter gillenii and Citrobacter sp. isolated from diseased rainbow trout (Oncorhynchus mykiss). Journal of Global Antimicrobial Resistance, 10, 136-142.

9. ISO 6579-1:2017 (2017). Microbiology of the food chain - Horizontal method for the detection, enumeration and serotyping of Salmonella - Part 1: Detection of Salmonella spp.

10. Janda, M.J., Abbott, S.L., Cheung K.W., Hanson, D.F. (1994). Biochemical identification of Citrobacteria in the clinical laboratory. Journal of Clinical Microbiology, 32 (8), 1850-1854.

11. Kolínská, R., Španelová, P., Drevínek, M., Hrabák, J., Žemličková, H. (2015). Species identification of strains belonging to genus Citrobacter using the biochemical method and MALDI-TOF mass spectrometry. Folia Microbiologica, 60, 53-59.

12. Kwak, H.L., Han, S.K., Park, S., Park, S.H., Shim, J.Y., Oh, M., Ricke, S.C., Kim, H.Y. (2015). Development of a rapid and accurate identification method for Citrobacter species isolated from pork products using a MatrixAssisted Laser-Desorption Ionization Time-ofFlight Mass Spectrofotometry (MALDI-Tof MS). Journal of Microbiology and Biotechnology, 25 (9), 1537-1541.

13. Murray, P.R. (2012). What is new in clinical microbiology-Microbial identification by MALDITOF Mass Spectrometry. The Journal of Molecular Diagnostics, 14 (5), 419-423.

14. Samonis, G., Karageorgopoulos, D.E., Kofteridis, D.P., Matthaiou, D.K., Sidiropoulou, V., Maraki, S., Falagas, M.E. (2009). Citrobacter infections in a general hospital: characteristics and outcomes. European Journal of Clinical Microbiology \& Infectious Diseases, 28 (1), 6168.

15. Thurm, V., Gericke, B. (1994). Identification of infant food as a vehicle in a nosocomial outbreak of Citrobacter freundii: epidemiological subtyping by allozyme, whole-cell protein and antibiotic resistance. Journal of Applied Bacteriology, 76, 553-558.

16. Tschape, H., Prager, R., Streckel, W., Fruth, A., Tietze, E., Böhme, G. (1995). Verotoxinogenic Citrobacter freundii associated with severe gastroenteritis and cases of haemolytic uraemic syndrome in a nursery school: green butter as the infection source. Epidemiology and Infection, 114, 441-450. 


\title{
ИДЕНТИФИКАЦИЈА CITROBACTER YOUNGAE ИЗОЛОВАНОГ ИЗ ХРАНЕ ПРИМЕНОМ МАLDI TOF МЕТОДЕ
}

\author{
Дубравка С. Миланов ${ }^{1}$, Милан Д. Ђилас ${ }^{2}$, Јелена М. Бабић, Бојана 3. Прунић ${ }^{1}$, Маја J. Велхнер ${ }^{1}$
}

${ }^{1}$ Научни институт за ветеринарство „Нови Сад“, 21000 Нови Сад, Руменачки пут 20, Србија

${ }^{2}$ Институт за јавно здравље Војводине, 21000 Нови Сад, Футошки пут 121, Србија

Сажетак: Из хране и хране за животиње понекада се изолују бактерије које су веома сличне салмонелама, као што су поједине врсте из рода Citrobacter. Испитивањем њихових биохемијских, а делимично и серолошких карактеристика (према одредбама Стандарда ISO 6579-1:2017), није могуће у потпуности искључити припадност роду Salmonella. Осим тога, лабораторије за микробиолошки преглед хране уобичајено немају дијагностичке могућности за прецизну идентификацију ових изолата до врсте. Из тих разлога сматрамо да је корисно приказати идентификацију врсте Citrobacter youngae применом MALDI TOF методе (MatrixAssisted-Laser-Desorption Ionization Time-of-Flight Mass Spectrometry). Поред диференцијалнодијагностичких критеријума у односу на Salmonella spp., у овом саопштењу укратко приказујемо релевантне податке о Citrobacter spp., опортунистичким патогенима из фамилије Enterobacteriaceae.

Кључне речи: Salmonella имитирајуће врсте бактерија, сир

Received: 26 July 2018

Received in revised form: 18 September 2018

Accepted: 19 October 2018 